\title{
Cultural and morphological characterization of Pochonia chlamydosporia and Lecanicillium psalliotae isolated from Meloidogyne mayaguensis eggs in Brazil
}

\author{
Jersys Arevalo ${ }^{1}$, Leopoldo Hidalgo-Díaz ${ }^{1}$, Irene Martins ${ }^{2}$, Janaína F. Souza ${ }^{2}$, José Mauro C. Castro ${ }^{3}$, Regina \\ Maria D.G. Carneiro² \& Myrian S. Tigano ${ }^{2}$ \\ ${ }^{1}$ Centro Nacional de Sanidad Agropecuaria, San José de las Lajas, Apartado 10, La Habana, Cuba; ${ }^{2}$ Embrapa Recursos \\ Genéticos e Biotecnologia, 70770-917, Brasília, DF, Brazil; ${ }^{3}$ Embrapa Semi-Árido, 56302-970, Petrolina, PE, Brazil
}

Author for Correspondence: Myrian S. Tigano, e-mail: myrian@cenargen.embrapa.br

\begin{abstract}
The root-knot nematode, Meloidogyne mayaguensis, causes serious economic loss to guava plantation in Brazil. Fungi associated with eggs of M. mayaguensis in Brazilian soil have not been studied yet, but this knowledge could form the basis for future field studies on biological control of this nematode. The egg parasitic fungi, Pochonia chlamydosporia var. chlamydosporia, P. chlamydosporia var. catenulata and Lecanicillium psalliotae, were isolated from M. mayaguensis eggs and analyzed based on their cultural and morphological characteristics. The optimum temperature for growth and spore production ranged between 24 and $28^{\circ} \mathrm{C}$ for $P$. chlamydosporia isolates. For the isolate of $L$. psalliotae, the best growth was at $30^{\circ} \mathrm{C}$. In solid state fermentation, P. chlamydosporia isolates produced between 3.5 and $5.2 \times 10^{6}$ chlamydospores per g of colonized substrate, whereas L. psalliotae isolate produced $8.5 \times 10^{8}$ conidia per g of colonized substrate. Future studies are required to clarify the potential of these fungi as biological control agents of M. mayaguensis.

Keywords: egg parasitic fungi, root-knot nematode, isolation, identification, optimum growing temperature.
\end{abstract}

\section{RESUMO}

Caracterização cultural e morfológica de Pochonia chlamydosporia e Lecanicillium psalliotae isolados de ovos de Meloidogyne mayaguensis no Brasil

O nematóide das galhas, Meloidogyne mayaguensis, causa sérias perdas econômicas em plantações de goiaba no Brasil. Fungos parasitas de ovos de M. mayaguensis ainda não foram estudados no Brasil, mas essas informações podem servir de base para estudos futuros de controle biológico em campo. Os fungos parasitas de ovos, Pochonia chlamydosporia var. chlamydosporia, P. chlamydosporia var. catenulata e Lecanicillium psalliotae foram isolados em ovos de M. mayaguensis e analisados quanto às suas características morfológicas e culturais. Para os isolados de $P$. chlamydosporia a melhor temperatura para crescimento e esporulação variou entre 24 e $28{ }^{\circ} \mathrm{C}$. Para o isolado de L. psalliotae, a melhor temperatura para crescimento foi $30^{\circ} \mathrm{C}$. Em estado sólido, os isolados de P. chlamydosporia produziram entre 3,5 e 5,2 x $10^{6}$ chlamidosporos por g de substrato colonizado, enquanto que o isolado de L. psalliotae produziu $8,5 \times 10^{8}$ conídios por $\mathrm{g}$ de substrato colonizado. Há necessidade de estudos futuros para mostrar o potencial desses fungos como agentes de controle biológico de M. mayaguensis.

Palavras-chave: fungos parasitas de ovos de nematóides, nematóide das galhas, isolamento, identificação, temperatura ótima de crescimento.

\section{INTRODUCTION}

Some soil-inhabiting fungi are nematophagous and have been used as biological control agents of harmful nematodes in agriculture (Stirling, 1991). Major groups of nematophagous fungi are facultative parasites and have the capacity to colonize plant roots (Bordallo et al., 2002; López-Llorca et al., 2002). Among the endoparasitic species, Paecilomyces lilacinus (Thom) Samson and Pochonia chlamydosporia (Goddard) Zare and W. Gams are notable as biological control agents of Meloidogyne spp. (Kerry, 2001).

P. chlamydosporia is a facultative parasite of eggs of sedentary cyst and root-knot nematodes and has been associated with nematode suppressive soils (Kerry et al., 1993). This fungus can colonize the rhizosphere without causing lesions to the plants or affecting plant growth, which represents an additional characteristic that facilitates its survival in soil in the absence of nematodes (de Leij \& Kerry, 1991).

Meloidogyne mayaguensis (Rammah \& Hirschmann) was recently reported causing serious economic damage to commercial guava (Psidium guajava) orchards in Brazil and, considering its wide spectrum of hosts, reproduction rate and virulence to different vegetable species with resistance genes to other Meloidogyne species, it represents a potentially aggressive pest for other economic crops in 
Brazil (Carneiro et al., 2001; 2007). The objective of this work was to isolate parasitic fungi from M. mayaguensis eggs, and study their cultural and morphological characteristics.

\section{MATERIALS AND METHODS}

\section{Isolation and identification}

Six randomized samples of $500 \mathrm{~g}$ of soil and infected roots were collected up to a depth of $10 \mathrm{~cm}$ from commercial guava plantations in Petrolina, PE, Brazil. This area is characterized by a semiarid climate: high temperature, low humidity and sandy soil, which is known to be heavily infested with $M$. mayaguensis (Carneiro et al., 2001). The samples were placed in plastic bags, and kept at $4^{\circ} \mathrm{C}$ until processed for isolation of nematode egg parasitic fungi. In the laboratory, roots of each sample were then washed, blotted dry, cut into $1 \mathrm{~cm}$ sections and mixed. Eighty egg-masses were picked up individually. Approximately 50 of them were mechanically disrupted before the eggs were suspended in $1 \mathrm{~mL}$ of $0.5 \%$ sterile agar solution, autoclaved at $121^{\circ} \mathrm{C}$ for $20 \mathrm{~min}$ and cooled at room temperature, and $0.2 \mathrm{~mL}$ of the suspension plated onto water agar (WA, Acumedia: $12 \mathrm{~g} \mathrm{~L}^{-1}$ ) containing 50 $\mathrm{mg} \mathrm{L}^{-1}$ of each of the following antibiotics: streptomycin sulphate, chloramphenicol and chlortetracycline in two Petri dishes $(9 \mathrm{~cm}$ diameter). They were incubated at $25^{\circ} \mathrm{C}$ for 14 to 48 hours to enable fungi to grow out from colonized eggs (Kerry \& Crump, 1977). Ten colonized eggs were picked at random from each plate and subcultured on corn meal agar (CMA $17 \mathrm{~g} \mathrm{~L}^{-1}$, Oxoid) for 14 days at $25^{\circ} \mathrm{C}$. The remaining 30 egg-masses were placed directly on a semi-selective medium for P. chlamydosporia (De Leij \& Kerry, 1991) and incubated at $25^{\circ} \mathrm{C}$ for 10 days. The eggmasses colonized by fungi were preliminarily observed in open Petri dishes using an optical microscope (x 100) to check for conidiophore branching patterns, arrangement of conidia and dictyochlamydospore production. From these observations, species of egg parasitic fungi could be distinguished (Gams, 1988). Fungi field isolates were selected for detailed studies on morphology, growth and sporulation, but they were not checked for egg parasitism.

\section{Cultural and morphometric characterization of the isolates}

For morphometric and cultural characterization, monosporic cultures were obtained for three isolates and stored at $4^{\circ} \mathrm{C}$ on potato dextrose agar (PDA, Difco: $39 \mathrm{~g}$ $\left.\mathrm{L}^{-1}\right)$. Agar plugs $(0.5 \mathrm{~cm}$ diameter $)$ from the edge of a colony grown in PDA at $15^{\circ} \mathrm{C}$ for 14 days were placed on the center of Petri dishes (9 $\mathrm{cm}$ diameter) containing malt extract agar (MEA, BioCen: $48 \mathrm{~g} \mathrm{~L}^{-1}$ ) and the plates incubated at $20^{\circ} \mathrm{C}$ in the dark. After 10 days, the radial growth of mycelia was measured and the following cultural characteristics determined: height, texture and color of both colony surfaces for five replicated Petri dishes for each isolate. For the microscopic characterization, microcultures were prepared on slides covered by a thin layer of water agar and incubated in a wet chamber at $25^{\circ} \mathrm{C}$ for a week. Then, a cover slide was placed on the fungal growth top and the dimensions of 50 conidia, a similar number of chlamydospores, and 25 phialides of each isolate were measured using an optical Axiophot microscope (1000 magnifications). In the case of an isolate that produced a mixture of large and small conidia, 25 conidia of each type were measured. The isolates were analyzed and described using the keys and species descriptions proposed by Zare et al. (2001) and Zare \& Gams (2001).

\section{Effect of temperature on growth and sporulation of isolates}

Temperature dependent linear growth rates for the above selected isolates were compared. Agar plugs ( $5 \mathrm{~mm}$ diameter) from the colony edges of these isolates were placed in the middle of $9 \mathrm{~mm}$-diameter Petri dishes containing PDA. Five replicates (Petri dishes) of each isolate were incubated at $20,24,28$ and $32^{\circ} \mathrm{C}$. After 72 hours, the colony diameter $(\mathrm{mm})$ was measured at 24 -hour intervals for 21 days and fungal growth day ${ }^{-1}$ estimated for the different temperatures. At the end of the experiment, each colony was washed with $5 \mathrm{~mL}$ of water agar $\left(0.5 \mathrm{~g} \mathrm{~L}^{-1}\right)$ using a glass rod and, depending on the isolate, numbers of chlamydospore or conidia were determined in a Neubauer chamber. An analysis of variance was carried out for each species and temperatures were studied using a general linear model. The means were compared by Duncan's multiple range test $(\mathrm{P} \leq 0.05)$, using regression analysis (SAS, Institute, 2001).

\section{Mass production on laboratory scale}

The Good Manufacturing Practice Guide developed at Centro Nacional de Sanidad Agropecuaria (CENSA) - Cuba for mass production of isolate IMI SD 187 of $P$. chlamydosporia var. catenulata (Kamyschko ex G.L. Barron \& Onions) Zare \& W. Gams in solid state fermentation in polypropylene bags (Montes de Oca, 2004) was used for the production of chlamydospores or conidia of each isolate in five replicated bags containing sterilized cracked rice grain $(250 \mathrm{~g})$. After 19 days of incubation at $25^{\circ} \mathrm{C}$, the colonized rice was mixed thoroughly in each bag and $1 \mathrm{~g}$ was added to $10 \mathrm{~mL}$ water agar $0.5 \%$ and vortexed to release the spores prior to counting in a Neubauer chamber. From a second decimal dilution $\left(10^{-2}\right), 0.2 \mathrm{ml}$ were placed and spread into $9 \mathrm{~cm}$-diameter Petri dishes containing WA and incubated at $25^{\circ} \mathrm{C}$ for 48 hours to evaluate the number of chlamydospores germinated. In the case of the isolate which produces conidia, the viability was evaluated by putting a drop of the conidia suspension on four points into $9 \mathrm{~cm}-$ diameter Petri dishes containing WA and incubated at $20^{\circ} \mathrm{C}$ for 21 hours. After that, one drop of lactic acid-cotton blue solution (3:1) was added and covered with slide to examine under optical microscope (1000 magnifications). The same 
protocol was online to determine the active biomass that the fungus expresses in colony forming unit (CFU) on PDA at $25^{\circ} \mathrm{C}$ for five days. An analysis of variance was carried out and the means were compared by Duncan's multiple range test $(\mathrm{P} \leq 0.05)(\mathrm{SAS}$, Institute, 2001).

\section{RESULTS AND DISCUSSION}

\section{Selected isolates for characterization studies}

Pochonia chlamydosporia var. chlamydosporia (CG1003) P. chlamydosporia var. catenulata (CG1006), and Lecanicillium psalliotae (Treschew) Zare \& W. Gams (CG1005) were isolated for the first time from $M$. mayaguensis eggs infecting a commercial guava plantation in Petrolina, PE, Brazil, where predominantly adverse conditions for soil fungi exist, such as high temperatures and semiarid climate. These isolates were deposited in the Culture Collection of Entomopathogenic Fungi at Embrapa Recursos Genéticos e Biotecnologia (CG).

The nematophagous fungus $P$. chlamydosporia is widespread and naturally occurring as a facultative parasite of root-knot nematode eggs. Selected isolates of this fungus have shown potential as biological agent of nematodes in field trials (Atkins et al., 2003a; Kiewnick \& Sikora, 2004). Lecanicillium psalliotae was originally described as the causal agent of a brown-spot disease in cultivated mushrooms, but it has subsequently been isolated from various other fungi and from a population of Globodera rostochiensis (Gams, 1988). It was reported for the first time in Cuba as an egg parasite of Meloidogyne spp. (Hidalgo et al., 2000a, b).

\section{Cultural and morphometric characterization of the isolates}

Cultural and morphometric characterization of isolates CG1003 and CG 1006 confirms the identification as $P$. chlamydosporia var. chlamydosporia and $P$. chlamydosporia var. catenulata, respectively, according to Zare et al. (2001). The two isolates presented, in ten days at $20^{\circ} \mathrm{C}$ on MEA, colonies reaching 2.3-2.7 cm diameter and $1.8 \mathrm{~mm}$ height, white cottony, with a light yellow center and regular edges. Conidiogenous cell were produced singly on vegetative hyphae or in two whorls on erect conidiophores. These descriptions also agree with that made by Hidalgo et al. (2000b) for Cuban isolates of both varieties of $P$. chlamydosporia, however, the presence of erect conidiophores is remarkable in the Brazilian isolates. Zare et al. (2001) considered that observing conidia arranged in chains or heads was sufficient to distinguish between isolates of one or another variety of $P$. chlamydosporia, but they also stated that the conidia in P. chlamydosporia var. catenulata are more globose to subglobose than those of var. chlamydosporia, which are more ellipsoidal. These morphological markers of the varieties were observed in the isolates CG1003 and CG1006.

Cultural and morphological characterization of the isolate CG 1005 confirms the identification as L. psalliotae, which is in accordance with the description of the species made by Zare \& Gams (2001), when this species was transferred from Verticillium to the genus Lecanicillium. Isolate CG 1005 presented, after ten days at $20^{\circ} \mathrm{C}$ on MEA, colonies reaching $3.5-3.8 \mathrm{~cm}$ diameter, white cottony, with a bulky growth in the center up to an average height of $3.6 \mathrm{~mm}$. Red to purple pigment diffused into the agar. Phialides produced singly on vegetative hyphae. Conidia transversely positioned on phialide, formed in small slimy head. These characteristics also agree with the description made by Hidalgo et al. (2000a) for a Cuban isolate of $L$. psalliotae obtained from Meloidogyne sp. eggs. The analysis of these cultural and morphometric characteristics allowed the identification performed in the preliminary examination of the isolates to be confirmed, although further studies on the identification and characterization at the molecular level are recommended (Atkins et al., 2003b; Hirsch et al., 2000).

\section{Temperature influence on growth and sporulation of isolates}

Growth at different temperatures was similar for all the isolates, regardless of the species or variety. The best growth temperatures were 24 and $28^{\circ} \mathrm{C}$, and regardless of the isolate, no significant difference was observed between these temperatures. The temperatures of $20^{\circ} \mathrm{C}$ and $32^{\circ} \mathrm{C}$ affected equally the growth of $P$. chamydosporia var. chlamydosporia (CG1003), whereas for P. chlamydosporia var. catenulata (CG1006) and L. psalliotae (CG1005), the temperature of $32^{\circ} \mathrm{C}$ caused lower growth than at $20^{\circ} \mathrm{C}$ (Table 1). At any temperature tested, L. psalliotae (CG1005) grew faster than $P$. chlamydosporia, while the two isolates did not show significant difference in the colony growth speed (Table 2).

In PDA, chlamydospore production differed between the isolates of $P$. chlamydosporia. For $P$. chamydosporia var. chlamydosporia (CG 1003), chlamydospore production was stable $(\mathrm{P} \leq 0.05)$ at $20^{\circ} \mathrm{C}, 24^{\circ} \mathrm{C}$ and $28^{\circ} \mathrm{C}$ and decreased $(\mathrm{P} \leq 0.05)$ at $32^{\circ} \mathrm{C}$, whereas for $P$. chlamydosporia var. catenulata (CG 1006) chlamydospore production increased $(\mathrm{P} \leq 0.05)$ at 24 and $28^{\circ} \mathrm{C}$ (Figure 1). Conidium production of L. psalliotae was highest at $20^{\circ} \mathrm{C}$ and decreased until $32^{\circ} \mathrm{C}$ (Figure 2). However, two Cuban isolates of L. psalliotae produced more conidia $/ \mathrm{mm}^{2}$ at $32^{\circ} \mathrm{C}$ than at $25^{\circ} \mathrm{C}$ (Hidalgo et al., 2000a).

\section{Mass production on laboratory scale}

The isolates analyzed were capable of growing and producing a sufficient number of spores using the biphasic methodology of mass reproduction. The behaviour of $P$. chlamydosporia isolates in the methodology applied agrees with the description done for the Cuban strain IMI SD 187, under similar conditions (Montes de Oca et al., 2005). No significant differences in spore production were observed between isolates of $P$. chlamydosporia. Chlamydospore production ranged between 3.5 and $5.2 \mathrm{x}$ 
Cultural and morphological characterization of Pochonia chlamydosporia...

TABLE 1 - Colony diameters (mm) of Pochonia chlamydosporia (CG1003 and CG 1006) and Lecanicillium psalliotae (CG1005), after 21 days' growth on PDA

\begin{tabular}{cccc}
\hline \hline Temperature & \multicolumn{3}{c}{ Isolate* } \\
\cline { 2 - 4 }$\left({ }^{\circ} \mathbf{C}\right)$ & $\mathbf{C G 1 0 0 3}$ & CG1005 & CG1006 \\
\hline 20 & $36.8 \mathrm{~b}$ & $61.4 \mathrm{~b}$ & $43.4 \mathrm{~b}$ \\
24 & $52.2 \mathrm{a}$ & $77.6 \mathrm{a}$ & $57.4 \mathrm{a}$ \\
28 & $53.6 \mathrm{a}$ & $78.3 \mathrm{a}$ & $59.5 \mathrm{a}$ \\
32 & $35.4 \mathrm{~b}$ & $55.2 \mathrm{c}$ & $36.6 \mathrm{c}$ \\
\hline
\end{tabular}

*Mean numbers with different lower-case letters in the same column differ significantly by Duncan's multiple range test $(\mathrm{P} \leq 0.05 \%)$

TABLE 2 - Colony growth speed (mm/day) of Pochonia chlamydosporia (CG1003 and CG1006) and Lecanicillium psalliotae (CG1005), after 21 days on PDA

\begin{tabular}{ccccc}
\hline \hline \multirow{2}{*}{ Isolate } & \multicolumn{4}{c}{ Temperature $\left({ }^{\circ} \mathbf{C}\right) *$} \\
\cline { 2 - 5 } & $\mathbf{2 0}$ & $\mathbf{2 4}$ & $\mathbf{2 8}$ & $\mathbf{3 2}$ \\
\hline CG1003 & $1.85 \mathrm{~b}$ & $2.57 \mathrm{~b}$ & $2.56 \mathrm{~b}$ & $1.53 \mathrm{~b}$ \\
CG1005 & $2.98 \mathrm{a}$ & $3.49 \mathrm{a}$ & $3.59 \mathrm{a}$ & $2.61 \mathrm{a}$ \\
CG1006 & $2.19 \mathrm{~b}$ & $2.87 \mathrm{~b}$ & $2.90 \mathrm{~b}$ & $1.77 \mathrm{~b}$ \\
\hline
\end{tabular}

*Mean numbers with different lower-case letters in the same column differ significantly by Duncan's multiple range test $(\mathrm{P} \leq 0.05 \%)$
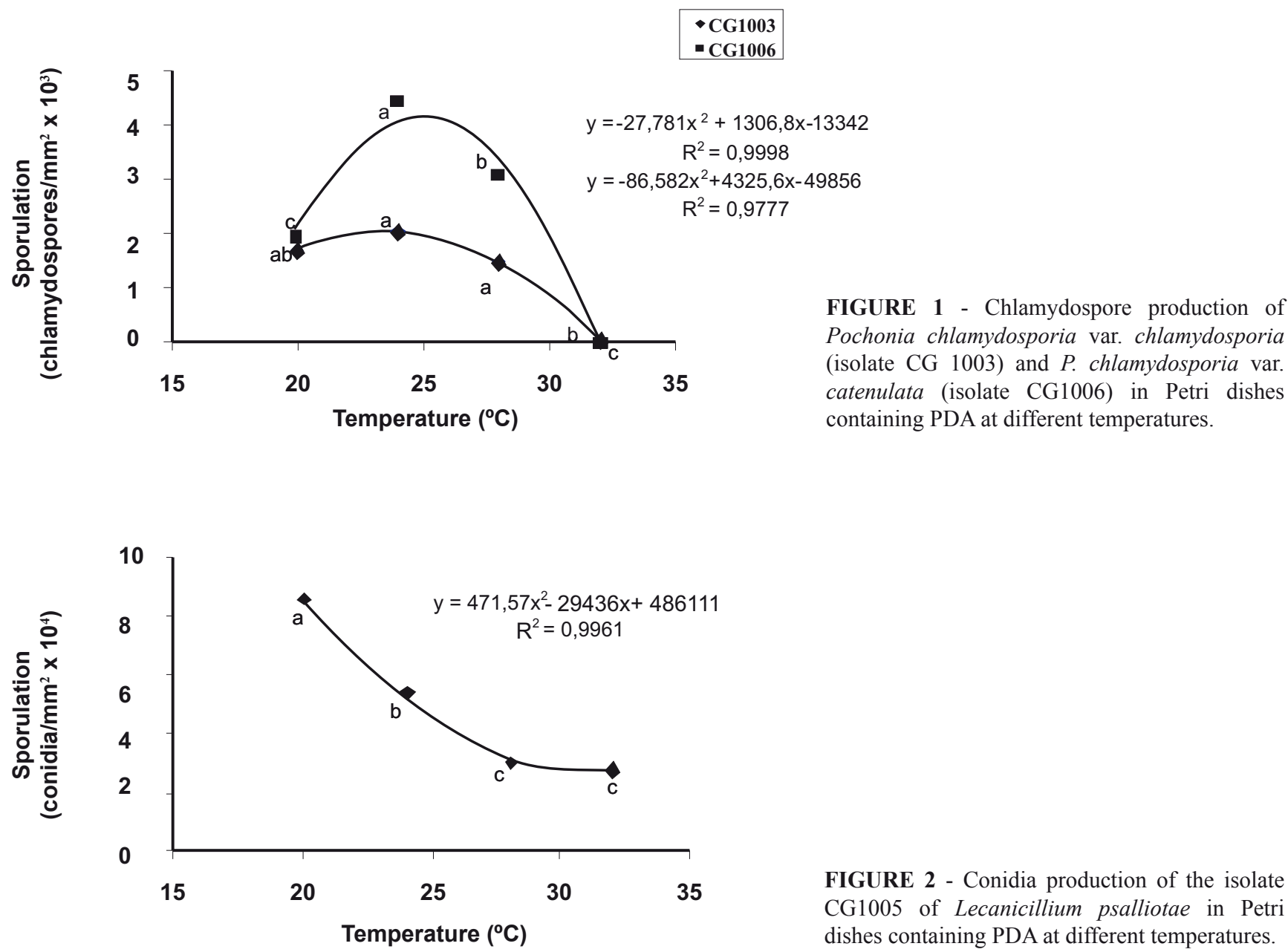

FIGURE 2 - Conidia production of the isolate CG1005 of Lecanicillium psalliotae in Petri dishes containing PDA at different temperatures. 
TABLE 3 - Sporulation of Pochonia chlamydosporia (CG1003 and CG1006) and Lecanicillium psalliotae (CG1005), after 19 days on solid state fermentation in polypropylene bags

\begin{tabular}{|c|c|c|c|}
\hline \multirow[t]{2}{*}{ Isolate } & \multicolumn{2}{|c|}{ Concentration* } & \multirow[t]{2}{*}{ Germination $(\%) *$} \\
\hline & $\left(\right.$ spores/g) $\times 10^{6}$ & $(\mathrm{CFU} / \mathrm{g}) \times 10^{7}$ & \\
\hline CG 1003 & $5.2 \mathrm{~b}$ & $9.2 \mathrm{~b}$ & $95.8 \mathrm{a}$ \\
\hline CG 1005 & $865.0 \mathrm{a}$ & $68.9 \mathrm{a}$ & $97.2 \mathrm{a}$ \\
\hline CG 1006 & $3.5 \mathrm{~b}$ & $11.2 \mathrm{~b}$ & $97.2 \mathrm{a}$ \\
\hline
\end{tabular}

*Mean numbers with different lower-case letters in the same column differ significantly by Duncan's multiple range test $(\mathrm{P} \leq 0.05 \%)$

$10^{6}$ chlamydospores per gram of substrate, with an average of $96.6 \%$ germination (Table 3). During growth on solid medium, a change in mycelium color from white to yellow was expressed for var. catenulata (CG1006), and from white to dark ochre for var. chlamydosporia (CG1003), due to chlamydospore formation. This is a characteristic of Pochonia, observed in the original description of the genus, and an important characteristic in fungal species with potential for use as a biological control agent, considering that this structure gives the fungus a higher persistence in the soil (Bourne et al., 1994).

In the case of $L$. psalliotae (CG1005), the growth in liquid medium showed a characteristic red color. A diffusing red pigment on agar medium was characterized as a dibenzoquinona, named oosporein, which was found to be a weak mycotoxin (Zare \& Gams, 2001). Using the same methodology of production, the isolate of $L$. psalliotae produced more spores $/ \mathrm{g}$ and $\mathrm{CFU} / \mathrm{g}$ than $P$. chlamydosporia, but spore germination was equal $(\mathrm{P} \leq 0.05)$ (Table 3$)$. Taking into account how easily these isolates grew and sporulated in vitro, their pathogenicity and virulence against $M$. mayaguensis should be tested in vivo in order to evaluate their potential as biological control agents.

\section{ACKNOWLEDGMENTS}

This research was supported by grants from the Ministry of Education of Cuba, Conselho Nacional de Desenvolvimento Científico e Tecnológico - CNPq and Embrapa.

\section{REFERENCES}

Atkins SD, Hidalgo L, Kalisz H, Muchline TH, Hirsch PR, Kerry, BR (2003a) Development of a new management strategy for the control of root-knot nematodes (Meloidogyne spp) in organic vegetable production. Pest Management Science 59:183-189.

Atkins SD, Hidalgo-Diaz, L, Clark IM, Morton CO, Montes de Oca N, Gray, PA, Kerry BR (2003b) Approaches for monitoring the release of Pochonia chlamydosporia var. catenulata, a biological control agent of root-knot nematodes. Mycological Research 107:206-212.

Bordallo JJ, Lopez-Llorca LV, Jansso HB, Salinas J, Persmark L, Asensio L (2002) Colonization of plant roots by egg-parasitic and nematode-trapping fungi. New Phytology 154:491-499.

Bourne Joanna M, Kerry BR, De Leij FAAM (1994) Methods for the study of Verticillium chlamydosporium in the rhizosphere. Journal of Nematology 26:587-591.

Carneiro RMDG, Moreira, WA, Alves MA, Gomes AC (2001) Primeiro registro de Meloidogyne mayaguensis em Goiabeira no Brasil. Nematologia Brasileira 25:223-228.

Carneiro RMDG, Almeida MRA, Braga RS, Almeida, CA, Gioria R (2007) Primeiro registro de Meloidogyne mayaguensis parasitando plantas de tomate e pimentão resistentes à meloidoginose no estado de São Paulo. Nematologia Brasileira 30:81-86.

De Leij FAAM, Kerry BR (1991) The nematophagous fungus Verticillium chlamydosporium Goddard, as a potential biological control agent for Meloidogyne arenaria (Neal) Chitwood. Revue de Nématologie 14:157-164.

Gams W (1988) A contribution to the knowledge of nematophagous species of Verticillium. Netherlands Journal of Plant Pathology 94:123-148.

Hidalgo-Diaz L, Bourne J, Kerry B (2000a) Verticillium psalliotae Treschews (Deuteromycotina: Hyphomycetes) as a parasite from eggs of Meloidogyne sp in Cuba: Characterization. Revista de Proteccion Vegetal 15:174-177.

Hidalgo-Díaz L, Bourne JM, Kerry BR, Rodríguez MG (2000b) Nematophagous Verticillium spp. in soils infested with Meloidogyne spp in Cuba: isolated and screening. International Journal of Pest Management 46:277-284.

Hirsch PR, Mauchline TH, Mendum TA, Kerry BR(2000) Detection of the nematophagous fungus Verticillium chlamydosporium in nematode-infested plant roots using PCR. Mycological Research 104: 435-439.

Kerry BR (2001) Exploitation of the Nematophagous Fungus Verticillium chlamydosporium Goddard for the Biological Control of Root-knot Nematodes (Meloidogyne spp.). In: Fungi as Biocontrol Agents: Progress, Problems and Potential. Butt TM., Jackson C, Magan N (Eds.) Wallingford. CAB International. pp. 155-168.

Kerry BR, Crump DH (1977) Observation on fungal parasites of females and eggs of the cereal cyst nematode, Heterodera avenae, and other cyst nematodes. Nematologica 23:193-201. 
Kerry BR, Kirkwood IA, De Leij FAAM, Barba J, Leidjens MB, Brookes PC (1993) Growth and survival of Verticillium chlamydosporium Goddard, a parasite of nematodes in soil. Biocontrol Science Technology 3:355-365.

Kiewnick S, Sikora RA (2004) Optimizing the biological control of plant-parasitic nematodes with Paecilomyces lilacinus strain 251. Phytopathology 94:S51.

Lopez-Llorca LV, Bordallo JJ, Salinas J, Monfort E, Lopez-Serna ML (2002) Use of light and scanning electron microscopy to examine colonisation of barley rhizosphere by the nematophagous fungus Verticillium chlamydosporium. Micron 33:61-67.

Montes de Oca N (2004) Buenas prácticas de fabricación para la obtención de un bionematicida a partir de la cepa Vcc 108 de Pochonia chlamydosporia var. catenulata. Tesis en opción al grado de Doctor en Ciencias Agrícolas. Universidad Agraria de la Habana - UNAH. Centro Nacional de Sanidad Agropecuaria CENSA. Havana, Cuba.
Montes de Oca N, Arévalos J, Acosta N, Hidalgo-Díaz L (2005) Herramientas para el control de la calidad de la cepa IMI SD 187 de Pochonia chlamydosporia var. catenulata (Kamyscho ex Barron y Onions) Zare y W. Gams. Revista de Protección Vegetal 20:86-92.

S.A.S. Statistical Analysis System, Release 8.02 (2001) Cary, NC. SAS Institute Inc.

Stirling GR (1991) Biological Control of Plant Parasitic Nematodes. Progress, problems and prospects. CAB International, Wallingford, UK.

Zare R, Gams W (2001) A revision of Verticillium section Prostrata. IV. The genera Lecanicillium and Simplicium gen. nov. Nova Hedwigia 73:1-50.

Zare R, Gams W, Evans HC (2001)A revision of Verticillium section Prostrata. V. The genus Pochonia, with notes on Rotiferophthora. Nova Hedwigia 73:51-86. 